\title{
Antioxidant activity and phenolic content of raw and blanched Amaranthus species
}

\begin{abstract}
The study was aimed to determine the antioxidant activity (total antioxidant and free radicalscavenging activities) and total phenolic content of Amaranthus sp. The effects of different blanching times (10 and $15 \mathrm{~min}$ ) on antioxidant activity and phenolic content were also studied. Four types of Amaranthus species locally known as spinach, namely óayam putihô (Amaranthus paniculatus) (BP), क́ayam merahô(Amaranthus gangeticus) (BM), óayam itikô (Amaranthus blitum) (BI) and óayam panjangô(Amaranthus viridis) (BPG), were selected. Total antioxidant activity of water-soluble components in raw spinach was in the order of BI å BM å BPG > BP, whereas free radical-scavenging activity was in the order of BI > BPG > $\mathrm{BM}>\mathrm{BP}$. The total phenolic contents of BM and BP were significantly higher $(\mathrm{p}<0.05)$ than other samples. All the studied spinach species possessed different antioxidant activities and phenolic contents. Antioxidant activities and phenolic contents of all the spinach were in the order of raw > blanched $10 \mathrm{~min}>$ blanched $15 \mathrm{~min}$. Blanching up to 15 min may affect losses of antioxidant activity and phenolic content, depending on the species of spinach.
\end{abstract}

Keyword: Spinach; Blanching; Total antioxidant activity; Scavenging activity; Phenolic content 